検討

北海道大学医学部附属病院放射線部

○菊池 務. 坪田秀一

X線写真の粒状の記録長は有限かつ離散的であり, 計 算機で解析（フーリエ変換）する場合種々のウィーナス ペクトル推定愦差を生ずる。これらはスペクトルの歪み や等価周波数バンド幅の影響による高周波での激しい振 動として表われるが，その評価はいわゆる決定論的な方 法では限界があり，即知スペクト礼からランダムデータ をシミュレーションし，FFT 法によるスペクトル誤差 と，ウィンドー好理の精度について検討した，方法はデ ータウィンドー及びスペクトルウィンドー処理によった が，处理スペクトルは既知スペクトルによく近似し，精 度及び安定性が評価された。またハイパス処理画像の粒 状性を測定し，本法によりスペクトル分解能が向上し to.

\section{3. ボケの視覚による最小認知の限界について}

星子丘厚生年金病院放射線部

○木村典子。辰畑 弘・十會敏夫 今田順久

大阪大学医療技術短期大学部：山下一也

[目的]視覚がボケ像しして認知する限界は，0.2〜 $0.3 \mathrm{~mm}$ といわれるが， 之の限界值は正確に求められた ものではない，命回，我々は，静止㧍よび 7 段階のボケ 像を，yes-no 実験，2肢強制選択法，7段階評価の 3 方 法により，評定実験を行い従来の限界值と比較した。

[結果] yes-no 奏験では，0.2 mm 以上のボケ像は， すべてがボケしして認知された．７段階評価では，0.16 $\mathrm{mm}$ のところで最す大きな゙゙ラッキを示していた.との ように，視覚によるボケの認知の界界は，従来言われて きた $0.2 \sim 0.3 \mathrm{~mm}$ よりもっと低い值， $0.16 \mathrm{~mm}$ 前後に あると考えられる。

\section{X線撮影系におけるフォトン数と照射線量の推定} 東芝医用機器事業部

○青木久敏・杉本 博. 安原 弘

[目的] X線撮影系における䈘のフォト数及び照射 線量を推定する方法の検討を行った。

[方法]実測のX線フォトンスペクトラムを用いて， 計算機のためのX線つォトンスペクトラムの実験式を作 り，全X線フォトン数度び照射線量を計算から求めるこ とを試みた。車に，フィルタ材による減弱を，それそれ の減弱係数の近似式より算出し，透過X線つォトンスペ クトラムを求め，透過全X線フォトン数及び透過線量を 計算によって求めた。 〔結果】＼cjkstart計算做と类測值は非常に良い一致をみた。と れにより，種々の条件におけるX線フォトン数及び照射 線量を容易に推定し得るようになった。

\section{5. 新しいアルゴリズムを用いた X線写真三次元計測 の方法と精度}

大阪大学歯学部歯科放射線科

○管家正筧·角田，明：速水昭宗

任意の二方向撮影された被写体の写真計測より，三次 元座標を再構成するアルゴリズムを，X線写真に応用し 検討した，再構成座栖の精度は，基準点の設定条件や焦 点・フィルム間距離によって変化するが，基準点によっ て囲まれる範囲内では，臨床的に $0.5 \mathrm{~mm}$ 以下にするこ とが可能であった。このアルゴリズムの利点は，焦点と フィルムの位置関係が任意であるため, 任意の方向と距 唯で撮影された二枚のフィルムより，再構成座標か計算 でき，焦点一フィルム間距離，管球移動距離等を測定す る必要肪なく，操作加簡単であるとと，特殊な装置を用 ゆないでも，良い精度で，三次元的計測が可能であるた め，臨床的応用範囲が広いてとである。

\section{座長集約}

撮影理論 6 は 8 つの演題よりなり,内 2 つは誌上発表, 残りの6つが口述発表であった。

198 席は，散乱線含有率を，奏験式办らの理論及び， 或測值から求めたものであった。特に質問はなかったが， 予稿の文中からは，実験で求める值と，理論から求める 值亡の区别がつきにくかった。

199 革, 200 席はシャウカステンに関するもので, 前 者は粒状を含めてシャウカステン輝度を検討し，後者は エントロピーで評価した。とれらには静岡学桨の松村よ り，シャウカステン照度の測定法について質問があり， 203 席己共に, この測定法の統一に問題を提起した. 又, エントロピーについては，山口大の大塚より入力と出力 の変数の説明がなく，まったくわからない，との質問と 共侳長芫解を求められた(後述).

201 席は，MTF 測定時のサンプリング数の検討で, サンプリング数が多いと雑音成分がスムージダされる とのととであった. これには肢皋工専の藤田より，ノィ ズ成分が多すぎる，にクロフィトメータのアパーチャサ イズに問題はないか，又，トランケーションエラーの方 がサンプリング点数以前に大事ではないかと質問があっ た。基本データと取り方がまず䦗題であるう。

202席はウィーナスペクトルを FFTで求める場合のウ インド処理の発表であった。熊本医短の吉田より，アパ ーチャサイズ，データ数等の質問があり，2 次元の断面 
をとらえるようなアパーチャサけズ用い,データ数は コンピンータの使用時間との閔係とあまりとれない, と 答えた。

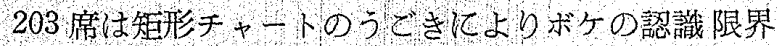

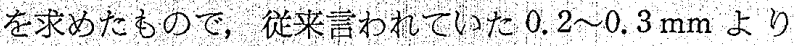
少ない0.16 mm といつ結果と得た。との演題とは熊本 䀢短の東田より矩形チャートを使用した場合コントラス

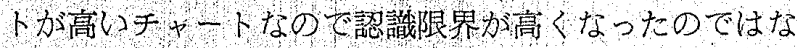

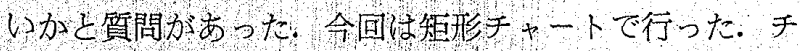

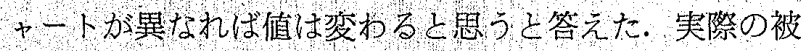

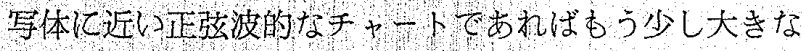
值しなるこあるっ.

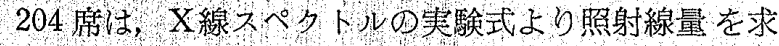

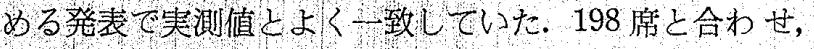
兵庫因大の伊藤々り前方散乱の奇与は惹盧されているか

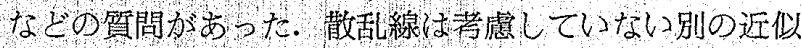

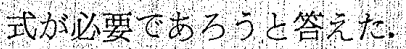

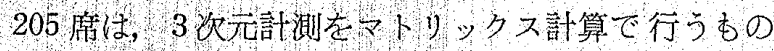

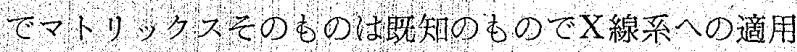

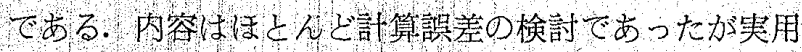
的 260 C 63 .

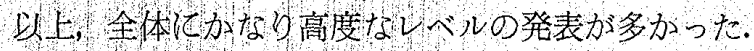

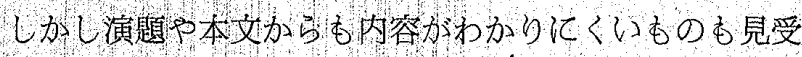

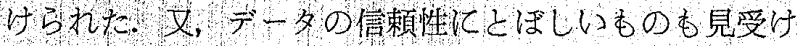
られた。基本テータの取りけに一考を望む。最後にェン トロヒー解析りいててあるか, とのセッションにかか わらさ内容不期なのが多かった・エントロピーは色及 なものの解析し用いるしとかてきるため, その入力, 出

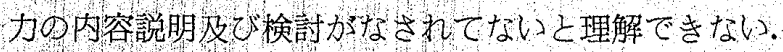

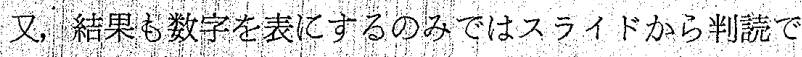

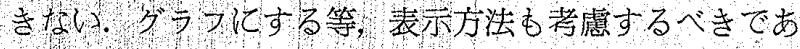

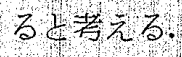

\section{診断用装置 -1 血管撮影装置}

䖯長 高尾義人 (長崎大学)

206. Axial (心缄) Cineangiography に対応できる遠隔 型可動つィルタの試作と固定台および被曝線量の 検討

\section{孔州厚生售金病院 放射線空

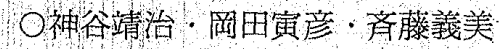 H村/䁷 - 岡部健玨}

T元U血管造影撮影法恃，従来の正面－側面同時（交

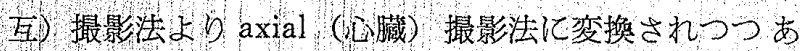

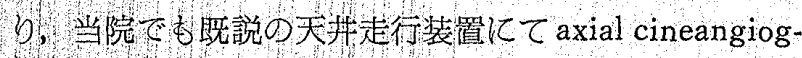

raphy を行なっているか，体位学換为大きく，との保持 が難しくなる。また撮影電圧の上旿に牦つ画質の劣化， 及び被曝線量の増加加著しり。

そとこ我々は三種類の動きを持つ适隔型可動つィルタ

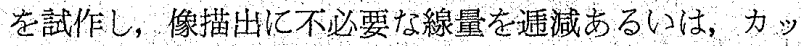
トすることにより，初期の目的である画質の同上及び被 曝線量䡜減が達成てきた。 また，おわせて專用固定台を 作成し，ての使用によって，妄全力つ再現性のあるAxial 体位が患児に苦痛を与えずできるようになった。

\section{7. 濃度補潩フィルタ内藏形シネ撮影用可動絞り}

(株) 日立×ディコ柏工場

O䄻井·司・加野学夫

山口罧済生会下関総合病院

磯山明一

心室・冠状動脈造影ンネ撮影において，肺野等の局部 的高濃度部の濃度補償による画質同上及びシネオートの 精度问上の試み己して補償つィルタの有用性が認められ つある。しかし，操作性，慔断部值制限等問題が多 (4).

今回，透視画像を見ながら外部から容易保作でき， いかなる撮影方向化刘しても操作できる改良形可動絞り を開発した。補傊つィル夕は，上用，左用，有用の各 3 種が具備され各々前後動，回転動作がてき，透視シネ撮 影飞おける画質力大幅に间上し，シネオートの精度向上 もはかられた。絪作器は，透視画像上に設定された配列 之同配列乙し操作の複雑さを解消した。尚, 補償つィル 夕は，画像の妨げとならない形状・材質て作られてい る.

208. X線フィルムチェンジャーにおけるプログラムセ レクト改良について

福岡放射線株式会社

○堤田哲夫。赤川達・山本義人

$\mathrm{X}$ 線つィルムチェンジーのプダラムャレタトにつ して, 従来のりレールよるシーチンス制御を全䦎して, 現在の四切フィルム秒間 2 枚，最大 12 枚の連続撮影操作 を行なうために、マイコンを導入した。操作手順をマ二 ュアルしオートに大別し，共につィルム数とィンタバ ルカウントをマイコンに入力しメもリする，操作のレデ イによりフィルムは準備され，X線スイッチにより撮影 するが, この㭙コンピュータは制御し演算好理をして動 作し，機械的作動の安定化とX線撮影画像の再現性を確 保した.フィルム確認は，パルス幅の升別回路採用で確 立され，X線装置加らの混入パルスはフォトカプラ採用 により，乙の種装置の愦動作を防止出来た。 